\title{
WOMEN IN INDIAN AND PAKISTANI POLITICS: RESERVATION POLICY AND QUOTAS VERSUS HUMAN DEVELOPMENT
}

\section{Agnieszka Nitza-Makowska*}

\begin{abstract}
This study compares the measures that serve women's numerical presence in politics in India and Pakistan. Based on the selected indicators of women's human development, the paper also outlines the socio-economic and cultural conditions under which these measures operate. Drawing mainly on the primary sources coupled with Indian and Pakistani movies, the paper concludes by exposing the gap between an average woman citizen and a woman politician that exists in both countries regardless of quotas and reservation policy.
\end{abstract}

Keywords: women in politics, quotas in Pakistan, reservation policy in India, women's human development 
Introduction

Indian and Pakistani hierarchical societies are divided along caste, language and religious lines ${ }^{1}$. Consequently, there is no single woman status that would apply to all, or even most, female citizens living in the countries. While one wins elections and becomes a prime minister, the other, when registering as a voter, introduces herself as a mother and a wife of her male family members. Indira Gandhi served as a prime minister of India long before any woman in Europe was appointed as the head of a government. Together with Benazir Bhutto, first female prime minister in Pakistan, they both gained international recognition. Airports, streets and restaurants were named after them in South Asia and beyond. Yet, the cases of women who are not confident enough to introduce themselves with their own names, and refer to their male family members, have outnumbered the success stories of women in Indian and Pakistani politics. "The diffidence of many women in northern India to give their own names, instead of which they wished to register themselves as A's mother or B's wife"' (Guha 2007, p. 134), was the second most serious problem, after India's geography, and the greatest surprise that the Election Commission faced when conducting the first general elections in India in 1951/ 1952. Consequently, to the practice, 2.8 million women failed to register themselves as voters (Ibidem, p. 134) vis-à-vis the total number of 172 million citizens ${ }^{2}$ on the electoral roll (Election Commission of India 1955, p. 68).

Since the first general elections in independent India (1951/ 1952) and Pakistan (1970), the female electorate has been gradually acquiring political and legal awareness. In India, due to the smooth democratiza-

\footnotetext{
1 Naturally, we bind the caste system with Hinduism and India, yet in the literature, the word caste is often used in the context of contemporary Pakistani society as well (Rais 2008, p. 444).

${ }^{2}$ The share of women eligible to vote is not provided for the first two general elections in India held in $1951 / 52$ and 1957.
} 
tion and regular elections, female citizens have been increasingly exercising their political rights. In Pakistan, with its turbulent regime's trajectory, the female electorate has had limited opportunities to vote and compete in elections.

However, in both countries, the voting rights themselves have failed to increase the numerical presence of women in politics to the level of the world average. In 1997, after five decades of the countries' existence, women held $7.3 \%$ and $2.6 \%$ seats in Indian and Pakistani parliaments, respectively, vis-à-vis the world average of 12\% (United Nations 2015, p. 121). In 2017, the share of seats in parliament held by women rose to $11.6 \%$ in India and 20\% in Pakistan while the world average reached 23.5\% (UNDP 2018a). The gender proportion in Pakistan's National Assembly, Senate and Provincial Assemblies increased notably only due to the quotas that have secured $17 \%$ of mandates for women since 2002.

This paper compares measures that serve the numerical presence of women in politics in India and Pakistan. Recognizing the measures' urgency, it 1) presents women's human development in the countries to outline the socio-economic and cultural conditions, under which the measures operate; and 2) juxtaposes the numerical presence of women in the legislative bodies where quotas or reservation policies apply vs the legislative bodies that lack these measures.

While outlying the socio-economic conditions in India and Pakistan, the paper relies vastly on the United Nations Development Program's (UNDP) data. However, statistics fail to draw a complete picture of Indian and Pakistani women's various statuses, mostly due to the countries' large and diverse populations. Accordingly, scholarly literature emphasizes these limits. In the book on India's economy, Domżalski (2017, p. 33) notices that in the case of statistics data "aggregation leads to the marginalization of some information that initially appears less important". 
Ramachandra Guha in India after Gandhi recommends abandoning statistics while explaining Indian democracy. Consequently, he devotes a chapter of the book to citizens' entertainments that focuses on Indian cinema (2008, pp. 720-734). I follow his advice and provide a few examples of movies that capture women's political and social performances. It allows to expand the perspective beyond statistics and helps notice the status' gap between an average female citizen and a female politician. Drawing mainly on the quantitative data, selected acts of law, media news, along with Indian and Pakistani movies, the paper concludes by exposing the gap that exists in both countries regardless of quotas and reservation policies.

Women's Human Development and Political Empowerment

There are several factors that set many Indian and Pakistani women back both economically and politically. Those are: prevailing low social status, poor or no education, accompanied by the widespread domestic and sexual violence These conditions, which are unfavorable to women's empowerment, are exposed by India's and Pakistan's performances in the HDI (Human Development Index) and the Freedom in the World Rank of the Freedom House (FH).

\section{Formal Education}

Although since 1990 the UNDP has reported some gradual improvements in human development in India and Pakistan, the countries' living conditions continue to lag behind the world average. The HDI (UNDP 2018b) ranks India and Pakistan 130th and 150th, respectively, out of 189 countries. Despite India is overtaking Pakistan, they both belong to the same medium development category. The HDI also exposes 
a gender gap in both countries. The selected indicators provided in Table 1, apart from male literacy rate and mean years of schooling in India, are significantly lower than the world's average. While those two indicators were close to the world average in 2017, Indian women continued to lag behind both their male counterparts and the world average for females. $18.2 \%$ of illiterate Indian women equals app. 240 million citizens. Hence, their population is almost three times larger than the population of Germany, the most populous European Union member state.

Table 1. Women's Human Development in India and Pakistan - Selected Indicators

\begin{tabular}{lccc}
\hline HDI Indicator & India & Pakistan & \multicolumn{1}{l}{ World average } \\
\hline Human Development Index (HDI), female & 0.575 & 0.465 & 0.705 \\
\hline Human Development Index (HDI), male & 0.683 & 0.620 & 0.749 \\
\hline Mean years of schooling, female (years) & 4.8 & 3.8 & 7.9 \\
\hline Mean years of schooling, male (years) & 8.2 & 6.5 & 9 \\
\hline Literacy rate, female (\% ages 15-24) & 81.8 & 65.5 & 85.5 \\
\hline Literacy rate, male (\% ages 15-24) & 90 & 79.8 & 90.7 \\
\hline Estimated gross national income per capita, female (2011 PPP \$) & 2722 & 1642 & 10986 \\
\hline Estimated gross national income per capita, male (2011 PPP \$)* & 9729 & 8786 & 19525 \\
\hline
\end{tabular}

"The report published in 2018 includes the data from 2011.

Source: The UNDP $2018 b$.

While most of the HDI indicators expose the gender gap, the two of them, the mean years of schooling and literacy rate (Table 1) are also key to political participation. Formal education has a potential to empower lower sections of societies and become a "specifically powerful predictor of political participation" (Burns, Schlozman, Verba 2001, p. 286). Its effects on political participation include the acquisition of knowledge and communication skills that are essential in the public 
debate, together with an improvement of civic skills of cooperation and negotiation used during political activity (Ibidem, pp. 141-142).

Indeed, in the hierarchical societies on the Indian subcontinent, education offers a rare opportunity to escape from difficult life conditions of discriminated groups, such as Dalits (untouchables), minorities and women. Abraham George, the founder of the Shanti Bhavan boarding school for Dalits and lower castes in Tamil Nadu, supports this important role of the education. Since 1997, when the school was established, he has been successfully passing this belief to his pupils. The documentary about the Shanti Bhavan (Roth 2017) follows several female students who commonly express their exceptionally strong commitment to education vis-à-vis an early marriage.

In Pakistan, an iconic advocate for female education is Malala Yousafzai, who began the struggle as a child living in the Talibancontrolled northwestern Swat valley in Khyber Pakhtunkhwa (KPK). She is the youngest-ever Noble Peace Prize laureate and one of the most influential people, according to Time magazine. Through Malala Fund which was founded in 2013, she continues to promote every girl's right to safe and qualitative education in Pakistan and beyond.

Yet, in her own country, she has been triggering a double-sided feeling. The Pew Research Centre (2014) survey shows that $86 \%$ of Pakistanis agree with Malala on the issue of education, as they confirm that education is equally important for both genders, yet the disapproval of her as a personality, has been widely registered in Pakistan. For instance, it manifested itself through the "I Am Not Malala" day that the All Pakistan Private Schools Federation organized to demand the banning of I Am Malala, Malala's memoir, in November 2014. 


\section{Violence and Victimization}

The prevailing low social status, followed by poor or no education, make Indian and Pakistani women from deprived sections of society dependent on male family members and exceptionally vulnerable to domestic and sexual violence. Women, who face the violence, continuously bear its economic and political consequences, including "poor social functioning skills and social isolation and marginalization; (...) lost workdays, lower productivity and lower income; overall reduced or lost educational, employment, social, or political participation opportunities" (UN Women n.d.).

The Freedom House (2013a) emphasizes the scale of the violence in its Freedom in the World reports. In India's case, 'Rape, harassment, and other transgressions against women are serious problems, and lower-caste and tribal women are particularly vulnerable... According to a recent National Health Survey, on average, one in three married women between ages 15 and 49 has experienced physical violence... The National Crime Records Bureau reports that about 6.000 females are killed every year for dowry-related issues alone". Accordingly, the growing violence against women, including rape cases, effectively challenges the image of "Incredible India", as the country promoted itself between 2002 and 2013.

Two thousand sixteen saw 38.947 reported rape cases in India (Chauhan 2017) vis-à-vis 96,970 rapes reported in the US (Statista 2018). Additionally, the number of reported rapes per 100.000 inhabitants in India equaled 2.94, which was less than in most European countries, including England and Wales (71.01), Sweden (64.06), France (14.05) and Germany (9.64) in 2016 (Eurostat 2018).

The statistics analyzed within a wider global context, suggest that India owns its label of the most dangerous country for women mostly due to the absolute number of incidents that are a result of the size of the population (over 13 billion population). Yet, the National Family Health Survey's data on violence against women together with women's daily life experiences 
challenge such perception. The National Family Health Survey's report claims that the systematical non-reporting of sexual violence prevails in India and lowers the statistics. Consisting of the reports of 79729 women, the survey reviled that between 2015 and 2016, 99.1\% of sexual violence acts faced by women went not reported (Bhattacharya, Kundu 2018). Bandit Queen (Bedi, Kapur 1994), an Indian moviebased on thelife of Phoolan Devi, Dalit women from rural Uttar Pradesh, exposes both untouchable women's vulnerability against sexual violence and the common non-reporting of crimes. The main character was a victim of numerous rapes. These crimes were perpetrated by Devi's peers from higher casts, own husband and police officers who kept her in custody. Neither of these cases were reported to the police.

As a result of the above, FH (2013b) in India, emphasizes cases of violence against women in Pakistan: "up to 80 per cent of women are victims of such abuse [rape, domestic abuse, and other forms of violence- including acid attacks] during their lifetime. (...) At least 913 women were killed by family members in so-called honor killings in 2012". Poor education, none or low income, and Pakistan's Islamization has been significantly jeopardizing women citizens to theseviolence cases. Thelaws, like Hudood Ordinances, introduced in order to Islamize the society, not only assume to harshly punish zina (extramarital sex) (The Offence of Zina Ordinance 1979) and qazf (false accusation of zina) (The Offence of Qazf Ordinance 1979), but also fail to treat men's and women's legal statuses equally. Consequently, the laws put a vast number of raped women into jails.

For instance, to confirm the accusation, woman's testimonies had to be supported by four male eyewitnesses of the crime. When the testimony lacks this support, women end up in jail being accused of qazf. It was only in 2006 when the Women's Protection Bill significantly revised the harmful laws. When Zia-ul-Haq, who forcefully triggered the Islamization and imposed the Hudud Ordinances, died in 1988, his legacy has been profoundly influencing Pakistan up to these days. 
Also, Pakistani movie Khuda Kay Liye (In the Name of God) (Mansoor 2007) exposes the approach of Islamists towards women. Yet, it distances Pakistan from the phenomena. The mullah who advises Sarma, one of the main characters, about the forced marriage, says "You cannot do it to a woman in Lahore, you have to go to Afghanistan". Consequently, the marriage happens in Afghanistan where Sarma joins the Taliban.

Marginalized by poor or no education and continuous victimization, Indian and Pakistani women need political empowerment and representatives who challenge the unfavorable socio-economic conditions on a larger scale than grassroots initiatives, such as the Malala Fund and Shanti Bhavan School. Female reservation policies or quotas can ensure the numerical presence of women in legislative bodies. Yet, these measures cannot guarantee the female legislators will effectively advocate for women's rights.

\section{Electoral Measures}

Under India's and Pakistan's socio-economic and cultural conditions, women require effective electoral measures in order to enter politics in significant numbers. Both countries, although to a different extent, recognized the need for such measures. While Pakistan introduced a quota system on central level and in provinces in 2002, India applied reservation policy for women only at the lower local levels in 1997.

Reservation Policy - India

India's reservation policy enhances the reservation of seats for Scheduled Castes (SC) and Scheduled Tribes (ST) on central and local levels ${ }^{3}$. The first category is designed for Dalits, the second one for tribal groups

${ }^{3}$ Another official classification, the Other Backward Classes (OBCs) designed for the socio-economically challenged societies that were not covered in the SC and ST lists, has no mandates reserved in the legislative bodies. 
called Adivasis. Yet, the policy omits minorities and, to a large extent, women. Only 1/ 3 of seats reserved at the lower local levels, particularly in Municipal Councils, Municipal Corporations and Panchayats ${ }^{4}$, are dedicated for female members (including $1 / 3$ of seats reserved for SC and ST). The Women's Reservation Bill (2008), or the Constitution (108th Amendment) Bill, that has not passed the parliament yet, guarantees women 1/ 3 of seats (including 1/ 3 of seats reserved for SC and ST) in the Lok Sabha (the lower house of Indian Parliament) and all Vidhan Sabhas (the assemblies of states/ union territories).

Although two India's leading parties: the INC and the BJ P, play the women reservation card 5 especially when elections are approaching, neither of them when in power, had addressed the case sufficiently. "The Bill was adopted by the Rajya Sabha [the upper house of Indian Parliament] in 2010. The distance between the Rajya Sabha and the Lok Sabha is just a five-minute walk. But the Bill has not moved for seven years. The Women's Reservation Bill is a victim of patriarchal power to ensure the status quo of male entitlement, said CPI(M)'s [Communist Party of India (Marxist)] politburo member Brinda Karat" (Chatterji 2017).

Although India developed an inclusive democracy (Desai 2005) that has experienced women, Dalits and members of minorities holding strategic offices in the country, the numerical presence of women in the legislative bodies at the central and state levels continues to lag behind the world average. Since 1952 the proportion of women in the Lok Sabha varied from $3.4 \%$ (in 1977) to $11.6 \%$ (in 2014). The proportion of women in the State/ Union Territory Assemblies varies across the country from $0 \%$ in Mizoram and Nagaland to $14.44 \%$ in Haryana (Table 2).

\footnotetext{
4 The Panchayat is a system of village-level (Gram Panchayat), block-level (Panchayat Samiti), and districtlevel (Zilla Parishad) councils, members of which are elected by the people, and are responsible for the administration of local public goods (Chattopadhyay, Duflo 2003, p.3).

5 For instance, both parties expressed their support for the women reservation in their election manifestos that were issued the year they won elections, in particular Lok Sabha Elections 2009 Manifesto of the Indian National Congress (INC 2009, p. 17) and Election Manifesto 2014 of the BJP (BJP 2014, p. 21).
} 
While in Madhya Pradesh, Puducherry, Rajasthan, West Bengal and Haryana the proportion of women is higher than in the Lok Sabha, in none of the states it reaches the world average.

Table 2. Women's Numerical Presence in the States Assemblies and Union Territories in India as of August 2017

\begin{tabular}{|c|c|c|}
\hline State/Union territory & Women MLAs/ Total MLAs & Percentage \\
\hline Mizoram & $0 / 40$ & o \\
\hline Nagaland & $0 / 60$ & o \\
\hline Karnataka & $6 / 224$ & 2.67 \\
\hline Arunachal Pradesh & $2 / 60$ & 3.33 \\
\hline Manipur & $2 / 60$ & 3.33 \\
\hline Jammu and Kashmir & $3 / 89$ & 3.37 \\
\hline Himachal Pradesh & $3 / 68$ & 4.41 \\
\hline Goa & $2 / 40$ & 5.00 \\
\hline Punjab & $6 / 117$ & 5.12 \\
\hline Kerala & $8 / 40$ & 5.71 \\
\hline Assam & $8 / 126$ & 6.34 \\
\hline Meghalaya & $4 / 60$ & 6.66 \\
\hline Maharashtra & $20 / 288$ & 6.94 \\
\hline Uttarakhand & $5 / 70$ & 7.14 \\
\hline Odisha & $11 / 147$ & 7.48 \\
\hline Telangana & $9 / 120$ & 7.50 \\
\hline Tripura & $5 / 60$ & 8.33 \\
\hline Delhi & $6 / 70$ & 8.50 \\
\hline Gujarat & $16 / 182$ & 8.79 \\
\hline Tamil Nadu & $21 / 235$ & 8.93 \\
\hline Sikkim & $3 / 32$ & 9.37 \\
\hline
\end{tabular}




\begin{tabular}{lcc}
\hline Jharkhand & $8 / 81$ & 9.87 \\
\hline Uttar Pradesh & $42 / 403$ & 10.42 \\
\hline Andhra Pradesh & $19 / 176$ & 10.79 \\
\hline Chhattisgarh & $10 / 90$ & 11.11 \\
\hline Bihar & $28 / 243$ & 11.5 \\
\hline Madhya Pradesh & $30 / 230$ & 13.04 \\
\hline Puducherry & $4 / 30$ & 13.33 \\
\hline Rajasthan & $28 / 200$ & 14.00 \\
\hline West Bengal & $42 / 297$ & 14.14 \\
\hline Haryana & $13 / 90$ & 14.44 \\
\hline Total & $364 / 4128$ & 8.81 \\
\hline
\end{tabular}

Source: Jamil H, Anmolam 2017.

The gender gap in numerical presence in the legislative bodies exists on the central and state/ union territory levels where reservation policies for women do not apply. Contrarily, "there has been substantial representation of women at local government levels that are subject to the reservation policies (...). There are 13.72 lakh $^{6}$ elected women representatives (EWRs) in PRIs (Panchayati Raj Institutions) which constitute of 44.2 per cent of total elected representatives (ERs) as on December 2017 (...) Women sarpanches accounted for 43 per cent of total gram panchayats (GPs) across the country, exhibiting active leadership of women in local" (PTI 2018). The comparison between the numerical presence of women in the legislative bodies on central and state levels versus lower local levels where their presence is secured by the reservation policy confirms that without the measure, women's numerical presence in Indian legislative bodies fails to meet the world average.

${ }^{6}$ In the Indian numbering system one lakh equal to one hundred thousand, 13.72 lakh equals to 1372 000. 
Quotas - Pakistan

Measures introduced in Pakistan, though of different kind than in India, were designed to enable citizens from the bottom of the social hierarchy to participate in politics. As a result, there are seats reserved in the National Assembly, Senate and Provincial Assemblies for women and representatives of religious minorities. In 2002, then-Pakistani President Pervez Musharraf announced that $17 \%$ of the seats in the upcoming elections to the National Assembly, Senate and Provincial Assemblies would be reserved for women. It means that out of 342 seats in the National Assembly, 60 are reserved for women. The quotas for provinces were revised by the Constitution (Eighteenth Amendment) Act, 2010 (Table 3).

Table 3. Quotas in Provincial Assemblies in Pakistan

\begin{tabular}{lcccc}
\hline Province & General mandates Women's mandates & Minorities' mandates & Total \\
\hline Baluchistan & 51 & 11 & 3 & 65 \\
\hline KPK & 99 & 22 & 3 & 124 \\
\hline Punjab & 297 & 66 & 8 & 371 \\
\hline Sindh & 130 & 29 & 9 & 168 \\
\hline
\end{tabular}

Source: Constitution (Eighteenth Amendment) Act 2010, point 36.

While in 2018 the number of women representatives in Baluchistan and KPK meet the quotas, the number of women in the Provincial Assemblies of Punjab and Sindh is higher. Six women in Punjab and two in Sindh were elected additionally to the quotas. 
The measures for women omitted two administrative territories of Gilgit-Baltistan, Azad J ammu and Kashmir, and the Federally Administered Tribal Areas (FATA). Together, they are inhabited by approximately 10 million people. The two administrative territories introduced their own quotas. According to them, six out of 33 seats are reserved for women in the Legislative Assembly of Gilgit-Baltistan and five out of 49 in the relevant legislative body in Azad J ammu and Kashmir. The FATA lacks female representatives on the local and central levels due to its traditional tribal character. The Constitution (Thirty-first Amendment) Act, 2018, which followed the FATA-KPK merger, grants the FATA with 21 seats, including four seats for women and one for a non-Muslim, in the 145-member KPK Assembly. FATA's female representatives and minority representative will be elected within a year after the 2018 Pakistani general elections.

Although the gender quotas significantly raised the female legislators' numerical presence, they failed to provide women with the representation capable of effectively acting in their interests. Sixty-nine females in the 15th National Assembly (60 due to the women quota, 1 elected to a non-Muslim seat, and 8 elected directly) are incapable of influencing the status of the average woman, who is restricted by her caste, religion and whether she lives in a rural or urban setting. Indigenous traditions continue to effectively prevent an average Pakistani woman from exercising her political rights in various provinces to different extents.

Dawn, a Pakistani newspaper, notes, "while we have a considerable number of women in parliament, womenfolk can still be barred from getting registered as voters and from casting their ballots" (Mehdi 2015). For instance, although over six thousand women were registered in each constituency in Dir districts (Lower and Upper Dir), none did cast a vote during the by-elections for the Provincial Assembly of KPK in December 2017 (Dawn Report. Not a Single Woman Cast Vote in 
Local Government By-Polls in Dir Districts 2017). The Election Commission's failure to provide female voters with polling stations and booths facilitated the implementation of the political parties' pre-election agreement to bar local women from voting. Since each of the winning candidates (mainly representatives of religious parties) received from 1,200 to 2,100 votes in their constituency, six thousand potential women's votes per constituency could have reversed these by-election results.

Women who Rule

While women from the lower sections of Indian and Pakistani societies struggle to receive formal education and exercise their political rights, their counterparts that belong to political clans can reach the highest positions in the countries. Indian movies often capture the subject of female's rule. Raajneeti (Deepak, Prakash 2010) shows a woman driving a family political party to electoral victory. In Gulaal (Kashyap 2008), a female candidate wins the brutal electoral battle over her male opponents. Phoolan Devi's leadership skills, as presented in Bandit Queen (Bedi, Kapur 1994), overcame the communal divide between Muslims and Hindus that stood shoulder to shoulder in her band.

The proportion of women in Municipal Councils, Municipal Corporations and Panchayats in India and the National Assembly, Senate and Provincial Assemblies in Pakistan is significantly higher comparing to their proportion in the legislative bodies where the electoral measures do not apply. Yet, the augmented numerical presence has not been followed by improvements in women's human development in any of these states.

Two years before Musharraf introduced the quotas, the Asian Development Bank (2000, p. 15) assumed that, in Pakistan's case, “women's inclusion in governance structures is critical to bring about substantive 
changes in the development policies and programs that would lead to a shift in gender relations in the society". Unfortunately, women improved numerical presence in the legislative bodies has failed to affect the gender imbalance in the country. In Pakistan, the side effect of the quotas explains it to some extent. Under the quota system, "women are acceptable only as proxies or an extension of male politicians" (Mehdi 2015). While female legislators' mandates do not depend on the electorate, but the party establishments, the female politicians lack the motivation to seek the voters', including that of women, support and target their problems.

Yet, India's case undermines the above perception. Despite the fact that Indian women are elected by citizens, they fail to address the daily problems of average women sufficiently. Some laws that could serve female citizens, such as the Women's Reservation Bill, have not been implemented, or, if introduced, they remain largely neglected.

For instance, The Dowry Prohibition Act of 1961, which forbids giving and accepting dowries; the Medical Termination of Pregnancy Act of 1971 and the Pre-natal Diagnostic Techniques (Regulation and Prevention of Misuse) Act of 1994 designed to target the sex selection of a fetus, due to Indians' unwillingness to raise daughters, are commonly disregarded. The two illegal practices are interconnected. The obligation to provide the future husband's family with a dowry encourages the abortion of a female fetus.

Regardless of who elect the female legislators, citizens or party establishments, women from political clans are commonly, yet not exclusively, appointed. Consequently, Indian and Pakistani politics seem a family affair. The characteristics serve the establishments that largely belongs to the political clans as Nehru-Gandhi, Yadav, Karunanidhi in India and Bhutto, Sharif, Soomro in Pakistan. Prime Ministers Indira Gandhi (1966-1977, 1980-1984) and Benazir Bhutto (1988-1990, 1993- 
1996) belonged to the families listed above. The first one was the daughter of J awaharlal Nehru, the first Prime Minister of independent India and who ruled the country for 17years (1947-1964). Zulfiqar Ali Bhutto, the father of the second, was a President (1971-1973) and then a Prime Minister (1973-1977) of Pakisan. He was hanged by his successor's - Zia ul-Haq - regime in 1979. Among the two-family political parties that the women Prime Ministers belonged to, Nehru-Gandhi's INC and Bhutto's PPP, the first one was recently ruled by a woman. Born as a Christian in Italy, Sonia Gandhi, who married Rajiv Gandhi in 1968, led the INC for nearly 20 years (March 1998-December 2017). Despite her gender, descent and religion, along with the INC' electoral rollback between the 2014 general elections and the November/ December 2018 assembly elections, she has remained one of the most powerful women in Indian politics.

Although relatively free and fair elections provide an opportunity to challenge that dynastical character of Indian and Pakistani regimes, the electorates refuse to seize it. Contrarily, Indians and Pakistanis commonly use the elections to express their commitment to the political clans by willingly casting votes for their members, regardless of the gender. In September 2017, the inhabitants of constituency no. 120 in Lahore, Pakistan demonstrated their support for the Sharif family by electing Kulsoom Nawaz after the disqualification of her husband, Nawaz Sharif. She won despite her health problems.

Indian and Pakistani dynasty regimes are hardly accessible to an ordinary citizen and vice versa, the representatives from privileged political clans hardly identify themselves with citizens from the bottom of the social hierarchy. "Generally, they did not see themselves as representing a woman's interests" as Kumari (1992, p. 126) wrote about a small group of elite women in Indian politics. Under the conditions of highly diverse and hierarchically organized societies, female legislators represent their families, casts, religions, not the gender. 
Conclusion

The trajectories of women's numerical presence in Indian and Pakistani politics demonstrate the measures' urgency. The voting rights themselves failed to rise women numerical presence to the level of the world average in the countries. While in Pakistan due to the quotas, party establishments assign most women representatives, Indian citizens elect female legislators on their own.

Yet, in both countries, the female legislators have refused to sufficiently address the socio-economic challenges that Indian and Pakistani women face every day as the UNDP statistics suggest. It can be explained by:

1) poor numerical presence of women in politics on central and states level in India,

2) the mechanism of Pakistan's quota under which women politicians are assigned by party establishments, not citizens,

3) women legislator's refusal to identify themselves with women electorate.

Under the hierarchical social order that forcefully differentiates and divides societies, female legislators represent their clans', cast's or party's interests.

Only the eventual introduction of the Women Representation Bill in India will reveal whether female representation reaching $33 \%$ in the legislative bodies has the potential to trigger Indian women's human development. Comparing to the suggested measures, Pakistani quotas which secure $17 \%$ of mandates, seem rather modest. Additionally, due to the quota's side effect, Pakistani female politicians are less expected to effectively advocate the women basic rights as their presence in politics does not depend on the electorate. 
References

Asian Development Bank (2000), Country Briefing Paper. Women in Pakistan, https:// www.adb.org/ sites/default/ files/ institutional-do cument/ 32562/ women-pakistan.pdf

Bedi B. (Producer), Kapur, S. (Director) (1994), Bandit Queen, India: Kaleidoscope Entertainment, Channel 4

Bhattacharya P., Kundu T. (2018), 99\% cases of sexual assaults go unreported, "Live mint”, https:// www.livemint.com/ Politics/AV3sIKo EBAGZozALMX8THK/99-cases-of-sexual-assaults-go-unreportedgovt-data-shows.html

BJ P (2014), Election Manifesto 2014, http:// www.bjp.org/images/ pdf_2014/full_manifesto_english_07.04.2014.pdf

Burns N., Schlozman K.L., Verba S. (2001), The Private Roots of Public Action: Gender, Equality, and Political Participation, Harvard University, Cambridge

Chatterji S. (2017), Political Will, Patriarchy: Why The Women's Reservation Bill Has Still Not Been Passed, "Hindustan Times", https:// www.hindustantimes.com/india-news/ political-will-patriarchy-why-the-women-s-reservation-bill-has-still-not-been-passed/ story-TB8ABRItzXm5QRuZaDSb5K.html

Chattopadhyay R., Duflo E. (2003), The Impact of Reservation in the Panchayati Raj: Evidence from a Nationwide Randomized Experiment, MT Economics, https:// economics.mit.edu/ files/ 769

Chauhan N. (2017), 2016 saw 106 rapes a day, Delhi the capital here too, "The Times of India”, http:/ / timesofindia.indiatimes.com/ articleshow/ 61872073.cms?utm_source=contentofinterest\&utm_medium=text\&utm_campaign=cppst

Constitution (Eighteenth Amendment) Act (2010), http:// www.pakistani.org/ pakistan/ constitution/ amendments/ 18amendment.html. 
Constitution (Thirty-first Amendment) Act (2018), http:/ / www.na.gov. pk/ uploads/ documents/ 1527169356_307.pdf

Dawn Report. Not a Single Woman Cast Vote in Local Government By-Polls in Dir Districts (2017), “Dawn”, https:// www.dawn.com/ news/ 1378923

Deepak Sh. (Director) \&, Prakash J . (2010), Raajneeti, [Motion Picture], India, Prakash J ha Productions Walkwater Media Ltd.

Desai M. (2005), Why India is a Democracy, (in:) Divided by Democracy, (Ed.) Page D., Roli Books, New Delhi

Domżalski S. (2017), Indie w gospodarce światowej. Słon, który pragnąt latać, Asian Century, Warszawa

Dowry Prohibition Act (1961), http:/ / wod.nic.in/ dowryprohibitionact.htm Election Commission of India (1955), Report on the First General Election in India 1951-52, Volume 1, https://eci.nic.in/ eci_main/ eci publications/ books/ genr/ FirstGenElection-51-52.pdf

Eurostat (2018), Violent sexual crimes recorded in the EU, https:// ec.europa.eu/ eurostat/ web/ products-eurostat-news/ -/ EDN-2017 1123-1?inheritRedirect=true

Freedom House (2013a), Freedom in the World 2013 - India, http:/ / www.freedomhouse.org/ report/ freedom-world/ 2013/india Freedom House (2013b), Freedom in the World 2013 - Pakistan, http:// www.freedomhouse.org/ report/ freedom-world/2013/pakistan Guha R. (2008), India after Gandhi. The History of the World's Largest Democracy, Macmillan, London

INC (2009), Lok Sabha Elections 2009 Manifesto of the Indian National Congress, http://www.indiaenvironmentportal.org.in/files/ Congress\%20Manifesto.pdf

Jamil H., Anmolam, (2017), Why Aren't We Dealing With the Lack of Women in Indian Politics, "The Wire", https://thewire.in/gender/ politics-womens-representation

Kashyap (Producer \&Director) (2008), Gulaal, [Motion Picture], India, Zee Limelight 
Kumari R. (1992), Women in Decision Making, Centre for Social Research Vikas Pub. House, New Delhi

Mansoor S. (Director \& Producer) (2007), Khuda Kay Liye, [Motion Picture], Pakistan, Shoman Productions

Medical Termination of Pregnancy Act (1971), http://tcw.nic.in/ Acts/ MTP-Act-1971.pdf

Mehdi T. (2015), Women in Politics, "Dawn", https://www.dawn. com/news/ 1183988

Offence of Qazf (Enforcement of Hudood) Ordinance (1979), Ordinance VIII of 1979, http:// www.pakistani.org/pakistan/legislation/ zia_po _1979/ord7_1979.html

Offence of Zina (Enforcement of Hudood) Ordinance (1979) - Ordinance VII of 1979 Ordinance No. VII of 1979, February 9th, http:// www.pakistani.org/ pakistan/legislation/zia_po_1979/ord7_1979.html

Pew Research Centre (2014), Most Pakistanis agree with Malala on educating girls, http:// www.pewresearch.org/ fact-tank/ 2014/ 10/ 10/ most-pakistanis-agree-with-malala-on-educating-girls/

Pre-natal Diagnostic Techniques (Regulation and Prevention of Misuse)

Act (1994), http:// chdslsa.gov.in/ right_menu/act/pdf/ PNDT.pdf PTI (2018), Women's political participation in India low, need more: Economic Survey, "The Economic Times", https://economic times.indiatimes.com/news/ politics-and-nation/ womens-politicalparticipation-in-india-low-need-more-economic-survey/ articles how/ 62696726.cms

Rais R.B. (2008), Pakistan, (in:) Electoral Processes and Governance In South Asia, (Ed.) Mendis D., SAGE, New Delhi

Roth V. (Producer \& Director) (2017), Daughters of Destiny, [Motion Picture], The US: Netflix

Statista (2018), Number of reported forcible rape cases in the United States from 1990 to 2017, https://www.statista.com/statistics/ 191137/ reported-forcible-rape-cases-in-the-usa-since-1990/ 
UN Woman (n.d.), Consequences and Costs, http:// www.endvawnow. org/ en/ articles/301-consequences-and-costs-.html

UNDP (2018a), Gender Inequality Index, http://hdr.undp.org/ en/ composite/ GII

UNDP (2018b), Human Development Index 2018, http://hdr.undp. org/ sites/default/files/2018_human_development_statistical_update.pdf

United Nations (2015), World's Women 2015: Trends and Statistics, New York, United Nations Department of Economic and Social Affairs, Statistics Division, https://unstats.un.org/ unsd/gender/ downloads/ worldswomen2015_report.pdf

Women's Reservation Bill (The Constitution 108th Amendment) (2008), PRS Legislative Research, https:/ / www.prsindia.org/ sites/ default/ files/bill_files/Women_Reservation_Bill_as_passed_on_Mar_9.pdf 